\title{
Self-efficacy beliefs of pre-service science teachers on fieldtrips
}

\author{
Ela Ayşe Köksal \\ Nigde Ömer Halisdemir University, Turkey \\ For correspondence: elaaysekoksal@gmail.com
}

\begin{abstract}
Science is comprised of theory and practical work and to study either part is not enough to understand the whole. Practical work such as observation and fieldtrips should be used to develop students' inquiry skills as well as to support the theory. Teachers with high self-efficacy on fieldtrips will be more likely to use this technique. Self-efficacy can be described as the perception of individual capacity. When the teacher candidates and teachers are considered, self-efficacy beliefs affect teachers' classroom practices and teachers with a high self-efficacy level are more passionate about teaching. This study intended to construct a self-efficacy scale for pre-service science teachers on using field-trips. The study also aimed to determine whether these beliefs vary by gender, class, secondary school type, whether fieldtrip was used in high school and university courses. Survey design was used in this study and the population was determined as all science education students at Turkish universities. The sample consisted of all 265 students at Niğde Ömer Halisdemir University. Data were collected by administering the "Self-Efficacy Beliefs on Fieldtrip Scale" by Öztürk (2008) to 249 pre-service science teachers. The students' responses were analysed in order to construct a self-efficacy scale. Item and scale analyses were done to assess the reliability of the scale and validity of the scores. Nonparametric tests were used to determine whether the beliefs differ according to those factors. Results showed that self-efficacy beliefs are multidimensional (consisted of task efficacy, coping with problems efficacy, teaching efficacy, and pre-visit actions efficacy); and pre-service teachers' beliefs were positive except coping with problems efficacy. The results also revealed that efficacy beliefs of the pre-service science teachers differed with gender (for pre-visit actions efficacy girls had higher scores than boys), the class level (pre-service teachers at lower grades had high efficacy on pre-visit and task efficacy compared to those at higher grades), and whether fieldtrips were used in high school (for task efficacy pre-service teachers whose high school courses were taught with fieldtrips had higher scores than those whose high school courses were not taught with fieldtrips. On the other hand no significant differences were found among pre-service teachers on class level, secondary school type, and whether fieldtrips were used in university courses.
\end{abstract}

Keywords: science, fieldtrips, self-efficacy beliefs, pre-service teachers, gender difference.

\section{Introduction}

Science is comprised of theory and practical work and to study either part is not enough to understand the whole. Practical work such as fieldtrips should be used to develop students' inquiry skills as well as to support the theory. According to Kaptan (1999), fieldtrip is a composition of fieldtrip and observation methods; the former is the onsite investigation of objects, tools, cases, and events that cannot be bring into the class, the latter is to make inferences about what is going on around them according to a plan, program by examining them (Kaptan, 1999).

Fieldtrip activities should be carried out in three stages; planning, sightseeing and evaluation after the tour (Kaptan, 1999). At the first stage, the teacher should arrange the area for excursion and determine the time of sightseeing; obtain necessary permits (such as parents, schools and the National Education Directorate); plan the fieldtrip by discussing the purpose, significance, scope, activities of the field study in class. The plan should also formulate the rules that must be followed during visit. In the second stage, travel and learning plans are harmonized. In the third stage, a classroom discussion about the trip class are held in order to evaluate the information and skills gained from the 
observations and examinations and the students organize what they learned in an examination report (Kaptan, 1999).

The usefulness of field trip method is to develop various skills and concepts, to evaluate evidence, to perceive change and continuity, and to establish empathy with the environment (Ata, 2002). Skill means the skills of listening, asking question, hypothesizing and communicating and the ability to work in groups (Ata, 2002). The concept is a common name given to the collection of events, ideas and objects with similar characteristics, for example animals can be grouped as vertebrate animals, mammals, birds, fish, reptiles and frogs (Kaptan, 1999). When evaluating the evidence, the animal is being classified by taking advantage of its observed characteristics (living environment, movement and feeding patterns). Changes in temperature during the day and relative changes in the position of the sun are observations that are used in the sense of change and continuity.

In addition, field trip activities give information about daily life of people who lived in the past, and help students perceive change and continuity by comparing this information with students' own living conditions (Ata, 2002). Examining the environment provides a better sense of value to protect it, since it will make it better to understand. In addition, historical monument and museum visits show that the physical evidence of the past is constantly threatened, and students develop a sense of responsibility towards cultural heritage (Ata, 2002).

A study on teachers' opinions about outdoor education revealed that teachers give importance to the activities at schools or homes but less prefer those like field trips because of the difficulties i.e., scarcity of facilities, curricula not designed to support these activities, security of students, administrative duties and interest of parents (Tatar \& Bağriyanık, 2012). Moreover, the studies on the effectiveness of field trip indicate that the method enhances the achievement in the teaching of history subjects in elementary social studies course (Açıköz, 2006), learning of communities in the biosphere in high school biology classes (Kaya, 2007).

Despite the mentioned positive aspects, the limitations of the trip-observation method are: Planning takes time; transportation and accommodation fees are arranged half a day or one day as the class population is crowded; disrupt the curriculum; weather is important in open space and learning experiences are limited if there is no preliminary preparation (Ata, 2002). Some of these limitations are in fact a reason why this method is not used by teachers in their classes. These limitations are some of the factors that influence the teacher's method selection (time-cost, number of students, ease of use, and targets to be reached). In addition to this, the teacher's skill in the method, the structure of the content, and the level of readiness of the students influence the choice of the method (Demirel, as cited in Dindar and Yaman, 2002).

The studies on the use of field trip method (Demir, 2009, Dindar and Yaman, 2002, Mazman, 2007) showed that the teachers of classroom, science and social studies who work in elementary schools rarely use excursions though they think it should be used frequently. The reason why fieldtrips are not used frequently in schools might stem from the general idea that knowledge is acquired in the classroom organized by the teachers and students' out-of-school experiences are unimportant (Uitto, Juuti, Lavonen, \& Meisalo, 2006). Especially in Turkey, individuals are expected to have a success on high stake tests and this negatively affects teachers' and students' participation into informal learning environments (Çeken, 2012).

The reason why teachers do not implement field trip method sufficiently is perhaps they are not being trained in this way during undergraduate training. As mentioned above, a teacher's knowledge and skill in a teaching method also determines her/his use of that method. In a study on pre-service level (Demir, 2007), it was found that the classroom teacher candidates have sufficient knowledge and 
experience to implement field trip method and they think that there are too many formalities, people and institutions have negative attitudes, that the financial impossibilities will be preventive, and that field trip in our country has not been implemented sufficiently for such reasons.

In other study, which examines the degree to which classroom teachers use methods and techniques included in the program in Life Study course, though it is stated in the program that active methods will be made use of, the teachers barely implement methods such as field trip and station, and techniques such as six hat thinking, speech cycle, and idea production. That study also showed that teacher guides and textbooks included traditional methods and techniques (Aykaç, 2011).

When viewed from this aspect, social studies program, which is prepared according to the constructivist approach, allows for discussion method such as brainstorming, which encourages students to think and develops their creativity, and makes use of expository method lesser than the previous program. The program is also positive for educating students, who thinks, discusses, and constructs their own learning. However teaching the subjects such as "What do you see in the nature, what are the common features of the living?" by examining only from pictures and photographs can prevent effective learning because it will create an abstract learning environment rather than concrete one. Considering the fact that the most effective learning can be achieved by prompting all the senses of the individual, it is not possible to realize an effective and productive learning process in an educational environment that does not allow learning by doing (experiential). From this point of view, it seems quite difficult for students to comprehend and to interpret life and close environment because the program compresses the learning process into textbooks and classroom environment and reduces the constructivist approach to discussion and image analysis methods. It is suggested therefore that the program should be revised in terms of activities, learning environment, methods and techniques, and materials (Aykaç, 2011).

In a study conducted with social studies teachers it was determined that fieldtrip method is included insufficiently into courses, only used to motivate students; students' undisciplined behaviours are the biggest problem faced during visit and verbal lecture is the mostly used activity after the visit (Gazel \& Yildırım, 2014).

In an experimental study conducted on Physical Geography in Social Studies Teaching program, the students instructed with fieldtrip were found as more successful than the control group with respect to the concept and phenomena of river erosion systems and geologic structure (ground), tectonic distribution, terrestrial shapes, and land use (Özgen, 2011). In another experimental study with preservice science teachers showed that the visit to an energy park contributed to learning in two ways: By learning new concepts and by conceptualising what is already known. This second way develops candidate teachers' both content and pedagogical content knowledge (PCK) (Cengiz \& Kabapinar, 2011).

According to Streule and Craig (2016), fieldtrips give a hand to the application of social learning theories because they supply opportunity for meaningful practical experience and contribute effective learning; are inherent for students creating a strong but changing sense of identity from student, to student, to practicing professional; and help students to develop and build their own communities of practice.

Therefore, postulates of social learning theory should be considered in field-trip programs. Students that most successfully participate in field trips are characterized by independence in their learning and increasing self-efficacy (Streule \& Craig, 2016), which can be described as the perception of individual capacity. Self-efficacy influences people's choice of activities and behavioral settings, how much effort they use up, and how long they will endure in the face of obstacles and aversive 
experiences (Bandura \& Adams, 1977). When the teacher candidates and teachers are considered, selfefficacy beliefs affect teachers' classroom practices and teachers with a high self-efficacy level are more passionate about teaching. Although, the perception of competence may not reflect the true competence; the sense of self-efficacy has an important role in regulating behaviour and practice.

Teachers with high self-efficacy on fieldtrips will be more likely to use this technique. A fieldtrip which was not used in accordance with the application steps will not serve the purposes of the course and the expected results will not be obtained (Gazel \& Yıldırım, 2014). For this reason, the perceptions of pre-service science teachers on their own capabilities of using this method should be investigated and solutions should be produced. In this study, pre-service science teachers' self-efficacy beliefs on fieldtrips and if these beliefs vary by gender, class, secondary school type, and whether fieldtrip was used in high school and university courses were tried to be determined. The study is important for the lesson and method and will be regarded as successful enough to contribute to the use of fieldtrip method (Gazel \& Yıldırım, 2014). Moreover research is needed to examine the soruces of teacher selfefficacy beliefs in different context (Gür, Çakıroğlu, \& Çapa Aydın, 2012). In this direction, the perceptions of pre-service science teachers at Nigde Ömer Halisdemir University regarding their capabilities on fieldtrip method which is an important method in science courses were taken in the 2012-13 academic year. The goal is to contribute to science instruction and use of the method in the direction of the beliefs and demographic factors determined.

This study intended to construct a self-efficacy scale on using field-trip in science education. The study also aimed to assess pre-service teachers according to some demographical variables on the self-efficacy constructs.

\section{Methodology}

Survey design was used in this study in order to assess pre-service science teachers' self-efficacy beliefs. The population was determined as all pre-service science teachers at Turkish universities. The sample consisted of all 249 students enrolled in science education department of Nigde Ömer Halisdemir University during 2012-13 academic year. Convenient sampling was used as sampling method. Since girls mostly prefer to be a teacher in Turkey, the majority of the students were female (74\%). $20 \%$ of the students were freshmen, $\% 28$ were sophomore $\% 24$ were junior, and $28 \%$ were senior. $58 \%$ of the students were attending the department during daytime, the remaining were in the evening education classes. High school types of the pre-service teachers they graduated from were as follows: Anatolian (\% 19), science (\% 2), normal (\% 62), vocational (\% 8), technical (\% 1) and other, i.e., Anatolian teacher, open (\% 8).

The data were gathered through a survey questionnaire which was developed previously by Öztürk (2008) for pre-service geography teachers. The students' responses were analysed in order to construct a self-efficacy scale through item and scale analyses.

Data were collected by administering the "Self-Efficacy Beliefs on Fieldtrip Scale" to 249 pre-service science teachers. Item and scale analyses were done to assess the reliability of the scale and validity of the scores. Since the data did not meet the assumptions of normality and homogeneity of variances, Mann-Whitney and Kruskal-Wallis tests were used to determine whether the beliefs differ according to those factors.

\section{Results}

Item Analyses

$\mathrm{r}$ (corrected item-total correlation coefficient) is Pearson bivariate correlation coefficient of each item score with the composite scores of the remaining items in the scale. It is also item discrimination, $r$, 
the extent to an item separates students who are successful on the overall test and those who are not. Although the criterion for $r$ is to be at least 250 (Kubiszyn \& Borich, 2007, Lester \& Bishop, 2000), it should not be less than zero or has a minus sign. The examination of the corrected item-total correlation values showed that no item has an $\mathrm{r}$ that is less than zero. All items were included for further analysis.

Reliability Analysis

Reliability is the correlation of an instrument with a hypothetical one measuring what is intended to measure. When the reliability is estimated with the correlations among the variables, namely the items, this kind of estimation is called Internal Consistency. Alpha should be at least .60 for exploratory studies (Garson, 2009). For 24 items, Cronbach's Alpha was found to be .77.

\section{Scale Analyses}

Scale selection was done according to factor analysis results in terms of KMO and Bartlett's Test, Total Variance Explained Table, Scree Plot, and Rotated (Varimax Factor Rotation) Component Matrix. The reason to use factor analysis was the dimensionality of self-efficacy beliefs. This beliefs have many features such as personal teaching efficacy and general teaching efficacy or influence on decision making, influence on school resources, instructional efficacy, disciplinary efficacy, enlisting parental involvement, enlisting community involvement, and creating a positive school climate, etc. (Tschannen-Moran, Woolfolk Hoy, \& Hoy, 1998).

The principal component analysis was selected as the extraction or factor analysis method. In this analysis, Kaiser's Criterion, which is extracting only the factors with an eigen value over one is met (Ashton, 2001). KMO is a measure of whether the distribution of values is adequate for conducting factor analysis. The value of KMO was found .7 and this is more than .6, which is considered for the factor analysis of the instrument to be meaningful. On the other hand, Bartlett Test of Sphericity was significant $(p=.00)$. This meant that the test data do not produce an identity matrix and approximately normal, and acceptable for factor analysis (George \& Malllery, 2003).

The total variance explained table shows how many factors with eigenvalues over 1 are there and how much these factors are responsible for the variance in the total test scores. This table showed up seven factors responsible for $55.837 \%$ of the variance in test scores.

Scree Plot is a representation of factors according to eigen values. This criterion asks to look at this graph and determine the breaks in the slope of the line (Ashton, 2001). Examination of this plot showed that there is a break after the fourth component. 


\section{Scree Plot}

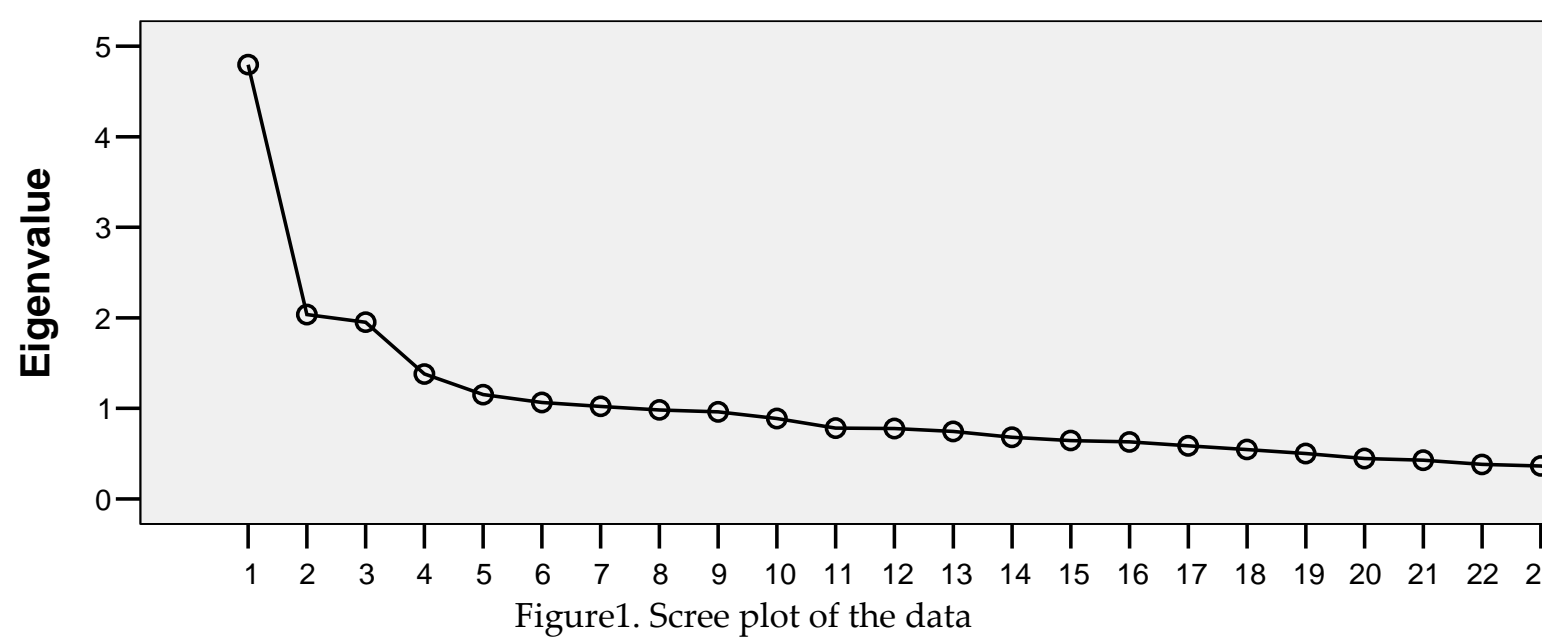

Rotated Component Matrix shows the items loaded to the factors when the data were reanalyzed with varimax rotation. This rotation hypothesizes that if there are underlying factors they will be highly correlated (Ashton, 2001).

Table 1. Factor Loading of the Items

\begin{tabular}{|c|c|c|c|c|}
\hline \multirow[t]{2}{*}{ item } & \multicolumn{3}{|c|}{ component } & \multirow[b]{2}{*}{ pre-visit } \\
\hline & anxiety & coping & teaching & \\
\hline 19 & ,727 & & & \\
\hline 4 & ,646 & & & \\
\hline 9 & 639 & & & \\
\hline 16 & .611 & & & \\
\hline 1 & 493 & & & \\
\hline 10 & & ,754 & & \\
\hline 7 & & ,747 & & \\
\hline 2 & &, 593 & & \\
\hline 20 & &, 533 & & \\
\hline 11 & & & .644 & \\
\hline 21 & & & .574 & \\
\hline 3 & & & .500 & \\
\hline 17 & & & & ,721 \\
\hline 15 & & & & .494 \\
\hline 12 & & & & ,478 \\
\hline 6 & & & & .380 \\
\hline 14 & & & & ,371 \\
\hline
\end{tabular}

Four factors were identified in this matrix:

1. Task self-efficacy: Perceived skill to behave and do accordingly.

2. Coping self-efficacy: Performance shown to cope with any difficulty.

3. Teaching self-efficacy: Performance shown to teach the subject by using fieldtrip method.

4. Pre-visit self-efficacy: Perceived skill to make arrangements for fieldtrip, i.e., to arrange the site, time; get permissions; to inform students about the fieldtrip; plan the trip. 
Table 2. Percentages and Means of the Items

\begin{tabular}{|c|c|c|c|c|c|c|c|c|}
\hline \multirow[t]{2}{*}{ factor } & \multirow[t]{2}{*}{ statement } & \multicolumn{5}{|c|}{$\%$} & \multirow[b]{2}{*}{ mean } & \multirow{2}{*}{$\begin{array}{l}\text { score } \\
\text { range }\end{array}$} \\
\hline & & 1 & 2 & 3 & 4 & 5 & & \\
\hline \multirow{5}{*}{ Task } & 19. I am happy to use fieldtrip & 2 & 3 & 12 & 39 & 44 & 4.21 & 5 \\
\hline & $\begin{array}{l}\text { 4. I believe that I will achieve the goals of fieldtrip } \\
\text { during application. }\end{array}$ & 1 & 2 & 12 & 58 & 27 & 4.09 & 4 \\
\hline & $\begin{array}{l}\text { 9. I am happy with my students in carrying out } \\
\text { fieldtrip. }\end{array}$ & 1 & 2 & 6 & 39 & 52 & 4.41 & 5 \\
\hline & 16. I do not prefer fieldtrip since it needs time. & 3 & 7 & 13 & 44 & 33 & 3.98 & 4 \\
\hline & $\begin{array}{l}\text { 1. I think that I will use fieldtrip in teaching science } \\
\text { as needed. }\end{array}$ & 1 & 4 & 16 & 49 & 30 & 4.02 & 4 \\
\hline \multirow{4}{*}{ Coping } & 10. I refrain from applying fieldtrip alone. & 11 & 20 & 29 & 24 & 16 & 3.16 & 3 \\
\hline & $\begin{array}{l}\text { 7. I do not know what to do with issues I may } \\
\text { encounter during fieldtrip. }\end{array}$ & 3 & 15 & 27 & 38 & 17 & 3.51 & 4 \\
\hline & 2. The responsibility of fieldtrip distresses me. & 4 & 20 & 26 & 33 & 17 & 3.41 & 4 \\
\hline & $\begin{array}{l}\text { 20. Fieldtrip is a method I will not prefer because I } \\
\text { do not want to take students' responsibility. }\end{array}$ & 4 & 10 & 16 & 41 & 29 & 3.80 & 4 \\
\hline \multirow[t]{3}{*}{ Teaching } & $\begin{array}{l}\text { 11. I may need to cooperate with specialists during } \\
\text { field studies of science. }\end{array}$ & 1 & 3 & 7 & 53 & 36 & 4.20 & 5 \\
\hline & $\begin{array}{l}\text { 21. I can discuss with science teacher very easily } \\
\text { with regard to the permits required to realize the } \\
\text { trip. }\end{array}$ & 2 & 10 & 29 & 38 & 21 & 3.65 & 4 \\
\hline & $\begin{array}{l}\text { 3. During the fieldtrip I can immediately connect } \\
\text { the subjects I taught with the places I go. }\end{array}$ & 1 & 3 & 15 & 58 & 23 & 4.00 & 4 \\
\hline \multirow[t]{5}{*}{ Pre-visit } & $\begin{array}{l}\text { 17. I must go and see the site in advance when } \\
\text { fieldtrip is to the neighbourhood industry, science } \\
\text { and technology museum, and galleries. }\end{array}$ & 1 & 7 & 9 & 41 & 42 & 4.15 & 4 \\
\hline & $\begin{array}{l}\text { 15. I do not wait for students to sleep if the trip is } \\
\text { planned as stay-overnight. }\end{array}$ & 3 & 7 & 10 & 32 & 48 & 4.15 & 4 \\
\hline & $\begin{array}{l}\text { 12. When fieldtrip is in the form of field study, civil } \\
\text { authorities do not need to be informed. }\end{array}$ & 5 & 8 & 11 & 41 & 35 & 3.92 & 4 \\
\hline & $\begin{array}{l}\text { 6. Before using fieldtrip, it will be useful to prepare } \\
\text { a brochure or board for the place to be visited. }\end{array}$ & 2 & 2 & 9 & 38 & 49 & 4.32 & 5 \\
\hline & $\begin{array}{l}\text { 14. The correspondence must be done carefully } \\
\text { before fieldtrip. }\end{array}$ & 3 & 2 & 4 & 35 & 56 & 4.39 & 5 \\
\hline
\end{tabular}

According to the Table 2, the mean score of pre-service teachers' beliefs were although positive, the scores were higher on the pre-visit and task efficacy dimensions (the mean scores were 4.18 and 4.14, which corresponds nearly to the "Completely Agree" range) compared to the coping with problems efficacy and teaching efficacy dimension (the mean score were 3.46 and 3.95 which corresponds to the "Agree" range). Considering the task efficacy, pre-service teachers mostly believe that they would be pleased to carry out fieldtrip with their students. They are also happy to use this method. Considering the pre-visit efficacy, pre-service teachers believe that correspondence should be done and information about the site should be given to the students before the trip. Considering the teaching efficacy, pre-service teachers found important to cooperate with specialist during trip. Considering the coping efficacy, pre-service teachers refrain from applying fieldtrip when they are alone.

On the other hand, self-efficacy beliefs of the pre-service science teachers differed with gender, and although there was no statistically significant difference between females and males on task efficacy 
$(U=5373.00, p=.35)$, coping efficacy $(U=5397.50, p=.38)$ and teaching efficacy $(U=5790.00, p=.93)$; for pre-visit actions efficacy, girls had higher scores than boys $(U=4654.00, p=.01)$.

According to the results, no statistical difference between task, coping, teaching, and pre-visit efficacy beliefs of pre-service teachers was found in different education groups $(U=7312.00, p=.65, U=$ 7524.50, $p=.94, U=7047.50, p=.35$ and $U=6734.00, p=.13$ respectively).

While $88 \%$ of the pre-service science teachers did not attend a trip in the high school, the percentage decreased to $72 \%$ in the university. To attend a fieldtrip in high school had a significant effect on preservice science teachers' self-efficacy beliefs, namely on task efficacy $(U=2469.50, p=.04)$ but not on coping, teaching and pre-visit efficacies compared to those whose high school courses were not taught with fieldtrips $(U=2676.50, p=.15 ; U=2579.50, p=.08$ and $U=2816.50, p=.30$ respectively). There was also no statistically significant difference between self-efficacy beliefs of pre-service teachers who attended a trip at university and those who did not on task, coping, teaching and previsit efficacies $(U=5608.50, p=.19 ; U=6103.50, p=.75 ; U=6207.00, p=.90$ and $U=5726.00, p=.28$ respectively).

Self-efficacy beliefs were found to be differed with grade level and pre-service teachers who were in the early years at the university had higher scores on task and pre-visit efficacy dimensions $(U=$ 5608.50, $p=.19 ; U=6103.50, p=.75 ; U=6207.00, p=.90$ and $U=5726.00, p=.28$ respectively). As a result of the Kruskal Wallis $\mathrm{H}$ test, which was performed to show if the mean rankings of self-efficacy beliefs scale differ with class level, statistically significant differences were found between the mean rankings of the grade groups on task and pre-visit efficacies $\left(X^{2}=9.63, p=.02\right.$ and $X^{2}=8.33, p=.04$ respectively). On the other hand, no statistically significant differences were found on coping and teaching efficacies $\left(X^{2}=2.87, p=.41\right.$ and $X^{2}=1.07, p=.78$ respectively). After this process, complementary comparison techniques were used to determine from which groups the determined significant difference originated. Since no specific test technique was used for this purpose, Mann Whitney U, preferred in binary comparisons, was applied. As a result of this analysis, it was determined that on task efficacy, there was a difference between freshmen and junior groups -visit efficacy in favour of freshmen compared to junior $(U=1129.50, p=.03)$, and between freshmen and senior groups in favour of freshmen $(U=1221.50, p=.00)$. On this efficacy dimension, the sophomore group differed significantly from seniors also $(U=1940.00, p=.03)$. On the other hand, there was a difference between freshmen and other groups with respect to pre-visit efficacy in favour of freshmen $(U=1371.00, p=.03 ; U=1142.00, p=.04$ and $U=1215.00, p=.00)$.

Self-efficacy scores of pre-service teachers did not differ with respect to the type of high school type they graduated from $\left(X^{2}=4.95, p=.42\right.$ and $X^{2}=2.62, p=.75 X^{2}=5.10, p=.40$ and $X^{2}=6.45, p=.26$ respectively).

\section{Conclusion}

Science lessons contain many phenomena and events that we encounter at any moment in life. To associate topics with everyday life and to observe, touch, and examine materials in the natural environment will assist students in achieving a meaningful and permanent learning. Field trips also improve the development of cognitive, affective, social and psychomotor skills of students (Tatar \& Bağriyanık, 2012). The development and identification of pre-service science teachers' self-efficacy beliefs on fieldtrips and the examination of factors affecting their beliefs may contribute to the development of programs on the subject.

With this study, in order to assess self-efficacy beliefs of pre-service science teachers on fieldtrips, a scale was developed, the components of the beliefs were compared, and it was tried to determine 
whether there is a meaningful difference between the belief components in terms of gender, class level, education group, high school type and attending a trip during high school or university variables.

When item and scale analysis were done, it was found that the scale is multidimensional and consisted of the task, teaching, coping, and pre-visit self-efficacies. Self-efficacy theory can be used to determine the beliefs of teacher candidates and teachers and predict their behaviours related to teacher tasks and responsibilities. When the level of self-efficacy is higher in a teacher, $s($ he) shows that level of eagerness, persuasiveness, and resistance. This will give important information on understanding and improving teacher behaviours (Bozdoğan \& Öztürk, 2008).

This research showed us that female pre-service teachers have higher scores on pre-visit efficacy than males. Pre-visit is the first step in a fieldtrip and it should be organised carefully in advance to increase the success of the following during visit and after visit activities. The higher scores of females at this dimension can be attributed to organisation skills and the belief on this capacity.

Though fieldtrip is a method of instruction, the high percentages of pre-service teachers who did not attend a trip at high school and university showed us that it is not preferred at high school and university. On the other hand, the condition is quite better at university. While $88 \%$ of the pre-service science teachers did not attend a trip in the high school, the percentage decreased to $72 \%$ in the university. The finding that pre-service teachers whose high school courses were taught with fieldtrips had higher scores than those not taught with fieldtrips implies that self-efficacy beliefs of the pre-service science teachers differ with the presence of an early experience with fieldtrips. As Orion and Hofstein (1994) suggest the quality (structure, materials, and method, and the ability to direct learning to a concrete interaction with the environment of a fieldtrip) and novelty space (cognitive, psychological and geographic variables) determine educational effectiveness of field trip, and the students whose novelty space was reduced before fieldtrip have higher learning performance. Thus students who are familiar with fieldtrip method have higher belief scores than those who do not have such experiences.

Similarly, at early grades pre-service teachers had higher scores on task and pre-visit efficacies and as they continue to their education their efficacy levels drop at higher grades. This can be contributed to the low rate of fieldtrips organised in university, and the gradual decrease on their self-efficacies. Efficacy beliefs are affected by social factors and efficacy expectations grow out of the following information sources (Bandura \& Adams, 1977):

1. Performance accomplishments provide the most influential efficacy information because it is based on personal mastery experiences.

2. Vicarious experiences of observing others succeed through their efforts,

3. Verbal persuasion that one possesses the capabilities to cope successfully,

4. States of physiological arousal from which people judge their level of anxiety and vulnerability to stress.

Therefore when personal efficacies do not supported by the social environment, they start to diminish.

On the other hand, no significant differences were found among pre-service teachers on secondary school type, and whether fieldtrips were used in university courses. It can be said that regardless of their type, high schools are in the same condition to apply fieldtrip. University courses although use fieldtrip more than those at high school, they do not have an impact on pre-service teachers' selfefficacy beliefs. 
Analysis of the mentioned variables gave the idea that there is no difference between these variables on pre-service teachers' coping and teaching efficacies. As outlined on Table 2, pre-service teachers had low scores on these dimensions. Inability to train themselves on how to cope with problems and what to do during the trip can be the reasons of this situation.

\section{Suggestion}

1. Since to attend trips at high school made a difference on task efficacy beliefs of pre-service teachers, the high school courses should be enriched with informal learning activities. Fieldtrips should be frequently included in the undergraduate training for the development of teacher candidates' knowledge and skills for out-of-school education. This way they can gain experience and perspective on the future education they will have (Tatar \& Bağrıyanık, 2012).

2. Schools and universities should be developed in terms of equipment and materials in order to give more practice areas for students (Aykaç, 2011). Pre-service institutions should be enriched with facilities that will be used in fieldtrips, i.e., a school museum is a best place to practice fieldtrip method for both science teacher educators and science teacher candidates.

3. In-service training activities should be organized for the development of teachers on teaching methods and techniques such as the development of an opinion that develops the creativity of the individual, active participation in the learning process, conversation ring, six-hat thinking technique, creative drama should be given wide coverage (Aykaç, 2011).

4. As science teaching and personal science teaching efficacy beliefs were found to be correlated with laboratory work self-efficacy (Mihlandız, Duran, Işık, \& Özdemir, 2011), fieldtrip self-efficacies can be compared with science teaching efficacy beliefs in order to develop pre-service teachers' teaching and the data can be used for concurrent validity o the scales as well.

\section{References}

Açikgöz, M. (2006). Sosyal bilgiler öğretiminde gezi-gözlem ve inceleme yönteminin etkililiğinin incelenmesi (Master's Thesis, Gazi University, 2006).

Ashton, K. R. (2001). The public image of psychologists: Development and validation of an attitudes toward psychologists scale (Doctoral Dissertation, Ohio State University, 2001), (UMI No, 3059195).

Ata, B. (2002). Müzelerle ve tarihî mekanlarla tarih öğretimi: tarih öğretmenlerinin "müze eğitimine" ilişkin görüşleri (Doctoral Dissertation. Gazi University, 2002).

Aykaç, N. (2011). Hayat bilgisi dersi öğretim programında kullanılan yöntem ve tekniklerin öğretmen görüşlerine göre değerlendirilmesi (Sinop ili örneği) [Evaluation of the methods and techniques used in knowledge of life course teaching program according to teacher opinions (Sinop case study)]. Kastamonu Ĕ̆itim Dergisi, 19, (1), 113-126.

Bandura, A., \& Adams, N. E. (1977). Analysis of self-efficacy theory of behavioral change. Cognitive Therapy and Research, 1 (4), 287-310.

Bozdoğan, A. E., \& Öztürk, Ç. (2008). Coğrafya ile ilişkili fen konularının öğretimine yönelik öz-yeterlilik inanç ölçeğinin geliştirilmesi [Improving of self - efficacy scale of geographyc coneptions embedded within 'science' course: A case for prospective science teachers] Necatibey Ĕ̆itim Fakültesi Elektronik Fen ve Matematik Ĕ̆itimi Dergisi Dergisi (EFMED) [Necatibey Faculty of Education Electronic Journal of Science and Mathematics Education], 2 (2), 66-81.

Cengiz, C., \& Kabapınar, F. (2011). Evaluation of the field trips to environments for informal learning: Case of the 'Energy Park'. Batı Anadolu Ĕ̆itim Dergisi [Western Anatolia Journal of Educational Science], 197-202.

Çeken, R. (2012). İlköğretim düzeyi öğrenci projelerinin biyoloji ile ilgili program dışı bilgiler yönünden içerik analizi [A content analysis of elementary student projects in terms of extra-curricular biological knowledge]. Necatibey Eğitim Fakültesi Elektronik Fen ve Matematik Eğitimi Dergisi (EFMED) [Necatibey Faculty of Education Electronic Journal of Science and Mathematics Education], 6(1), 55-66.

Demir, M., K. (2007).Sınıf öğretmeni adaylarının gözlem gezisi yöntemine bakış açılarının incelenmesi. Gü, Gazi Ĕ̆̆itim Fakültesi Dergisi, 27 (3), 83-98.

Demir, M. K. (2009). Sınıf öğretmenlerinin gözlem gezilerine yönelik tutum ve görüşlerinin incelenmesi. Kastamonu Ĕ̆itim Dergisi, 17 (2), 467-478.

Dindar, H., \& Yaman, S. (2002). Öğretmenlerin ilköğretim 4. ve 5. sınıflarda fen bilgisi dersinde öğretim yöntemlerini kullanma durumları. Kastamonu Ĕ̆itim Dergisi, 10 (1), 103-108. 
Garson, D., G. (2009). “Reliability Analysis, Reliability Analysis: Statnotes from North Carolina State University, Public Administration Program" http://www2.chass.ncsu.edu/garson/pa765/reliab.htm. (accessed April 2017).

Gazel, A. A., \& Yıldırım, R. (2014). İlköğretim II. kademe sosyal bilgiler derslerinde gezi-gözlem yönteminin uygulanma durumunun incelenmesi [Study of application for excursion observation method in primary school 2nd grade social studies]. Kuramsal Eğitimbilim Dergisi [Journal of Theoretical Educational Science], 7(2), 246-270.

George, D., \& Mallery, P. (2003). SPSS for windows step by step: A simple guide and reference 11.0 update (4th ed.), Munich: Allyn \& Bacon.

Gömleksiz, M. N., \& Bulut, İ. (2007). Yeni Hayat Bilgisi Dersi Öğretim Programının Uygulamadaki Etkililiğinin Değerlendirilmesi, Millî Ĕ̆itim, 173, 67-88.

Güneş, T., \& Demir, S. İlköğretim Müfredatındaki Hayat Bilgisi Derslerinin, Öğrencileri Fen Öğrenmeye Hazırlamadaki Etkileri. Hacettepe Üniversitesi Ĕ̆itim Fakültesi Dergisi, 33, 169-180, (2007).

Gür, G., Çakıroğlu, J., \& Çapa Aydın, Y. (2012). Investigating predictors of sense of efficacy beliefs of classroom, science, and mathematics teachers. Ĕgitim ve Bilim [Education and Science], 37(166), 68-76.

Kaptan, F. (1999). Fen Bilgisi Öğretimi. İstanbul: Milli Eğiitm Bakanlı̆̆1.

Kubiszyn, T., \& Borich, G. (2007). Educational testing and measurement: Classroom application and practice (8th ed,). Hoboken, New Jersey: John Wiley \& Sons, Inc.

Mazman, F. (2007). Sosyal bilgiler eğitiminde gezi-gözlem metodunun uygulanmasına ilişkin bir araştırma (Tokat örneği) (Master's Thesis, Gaziosmanpaşa University, 2007).

Mcmillan, J. H., \& Schumacher, S. (2006). Research in education. Boston: Pearson Education Inc.,.

Mıhlandız, G., Duran, M., Işı1k, H., \& Özdemir, O. (2011). The relationship between the pre-service science teachers' self-efficacy beliefs about science teaching and laboratory works. Batı Anadolu Eğitm Dergisi [Western Anatolia Journal of Educational Science], 477-484.

Orion, N., \& Hofstein, A. (1994). Factors that influence learning during a scientific field trip in a natural environment. Journal of Research in Science Teaching, 31(10), 1097-1119.

Özgen, N (2011). Fiziki coğrafya dersi öğretim metoduna farklı bir yaklaşım: gezi- gözlem destekli öğretim [A different approach to physical geography teaching method: Trip-Observation supported education]. Marmara Coğrafya Dergisi, (23), 373-388.

Öztürk, Ç. (2008). Coğrafya öğretiminde gezi-gözlem tekniğini kullanabilme öz-yeterlilik inanç ölçeğinin geliştirilmesi [Developing a scale of self-efficacy belief about using fieldtrip method in teaching of geography]. Ondokuz Mayıs Üniversitesi Eğitim Fakültesi Dergisi, 25, 13-23. http://www.pegem.net/dosyalar/dokuman/124565-20110819145941-25-13cografya.pdf

Streule, M. J., \& Craig, L. E. (2016). Social learning theories-An important design consideration for geoscience fieldwork. Journal of Geoscience Education, 64 (2), 101-107.

Tatar, N., \& Bağrıyanık, K. E. (2012). Fen ve teknoloji dersi öğretmenlerinin okul dışı eğitime yönelik görüğleri [Opinions of science and technology teachers about outdoor education]. Ilköğretim Online [Elementary Education Online], 11(4), 883896.

Tschannen-Moran, M., Woolfolk Hoy, A. \& Hoy, W. K. (1998). Teacher efficacy: Its meaning and measure. Review of Educational Research, 68, $202-248$.

Uitto, A., Juuti, K., Lavonen, J., \& Meisalo, V. (2006). Students' interest in biology and their out-of-school experiences. Journal of Biological Education, 40(3), 124-129. 